\title{
İnşaat Proje Organizasyonlarında Kişiler Arası Çatışma Çözüm Yaklaşımları ile Kişilik Özellikleri Arasındaki İlişki
}

\author{
Tülay Çivící ${ }^{* 1}$ \\ ${ }^{1}$ Balıkesir Üniversitesi, Mimarlık Fakültesi, Mimarlık Bölümü, Balıkesir
}

Geliş tarihi: 24.05.2019 Kabul tarihi: 30.09.2019

$\ddot{O} z$

Bu çalışmada, inşaat proje organizasyonlarında kişilerarası çatışma çözüm yaklaşımları ile kişilik özellikleri arasındaki ilişki incelenmiştir. Bunun için mimarlık/mühendislik ofisi ve şantiyede (yüklenici/tedarikçi) çalışan mimar ve inşaat mühendisine yönelik anket çalışması yapılmıştır. Anket çalışmasında çatışma çözüm yaklaşımı ölçeği ve beş faktör kişilik özellikleri ölçeği kullanılmış, veriler istatistiksel olarak incelenmiş, kişilik özellikleri ile çatışma çözüm yaklaşımları arasındaki ilişki ortaya konulmuştur. Bulgular, katılımcıların yüksek düzeyde problem çözme ve uzlaşma çatışma çözüm yaklaşımlarını benimsediklerini göstermektedir. Ayrıca bulgular, katılımcıların dışadönük, sorumluluk sahibi ve deneyime açık kişilik özellikleri gösteren bireyler oldukları yönündedir.

Anahtar Kelimeler: İnşaat sektörü, Çatışma çözüm, Kişilik özellikleri

\section{The Relationship between Conflict Resolution Approaches and Personality Characteristics of Construction Project Organization}

\begin{abstract}
In this study, the relationship between conflict resolution approaches and personality characteristics of architects and civil engineers working in construction sector was investigated. For this purpose, a survey was conducted for architect and civil engineer working in architecture/engineering office and construction site (contractor/supplier). In the questionnaire, conflict resolution approach scale" and "five-factor personality caharacteristics scale" were used and the data were analyzed statistically. The findings show that the personality charactersistics an important role in the adoption of conflict resolution approaches.
\end{abstract}

Keywords: Construction industry, Conflict resolution, Personality characteristic

*Sorumlu yazar (Corresponding author): Tülay Çivici, tulay@balikesir.edu.tr 


\section{GíRiș}

Bireyler birbirinden faklı algı, bilgi, amaç, ihtiyaç, değer, inanç, kişilik özelliklerine sahiptir. Bu farklılıklara bağlı olarak, çalışma ortamında benzer durum/olaylar karşısında farklı tepkiler vermektedir [1]. Bu durumda kişilerarası çatışmayı kaçınılmaz olmaktadır. Kişilerarası çatışma ise, insan faktörünün ağırlıklı olduğu çalışma ortamlarının bir parçasıdır.

İnşaat sektörü, farklı bakış açıları, yetenekleri ve bilgi düzeyindeki katılımcıların birlikte çalıştığı proje temelli organizasyon yapısıyla karmaşık ve rekabetçi bir çalışma ortamıdır [2,3]. Çatışma bu çalışma ortamında inşaat projelerinin başarılı bir şekilde tamamlanmasını engelleyen etkenlerden biridir [4,5]. Proje organizasyonlarında iletişim ve koordinasyon eksiklikleri, bilgi paylaşımının yetersizliği, yönetimde denetim ve koordinasyon yetersizliği, takım ruhunun zayıf olması, teknolojik değişimler, yasal düzenlemeler, çalışma ortamının belirsizlik ve risk içermesi, sözleşme şartlarının belirsizliği, kıt kaynak nedeniyle malzeme tedarik aşamasında karşılaşılan zorluklar, tasarımlarım ve yapım arasındaki uyuşmazlık, profesyonellikten yoksunluk ve proje ekibi stresinin gibi pek çok etken paydaşlar arasında çatışmanın nedenleri olabilmektedir [4-7].

İnşaat projelerinde tasarım aşamasından yapım aşamasına kadar insan faaliyetleri ağırlıklıdır. Bu bakış açsıyla inşaat insan faaliyetidir [6-10]. İnsan faktörünün etkin rol oynadığ 1 inşaat sektöründe paydaşlar (mal sahipleri, yükleniciler, meslek profesyonelleri, vb.) arası ilişkiler inşaat projelerinin başarısında önemli bir unsurdur. İnşaat projelerinde esas amaçlarının planlanan zaman, kabul edilen kalite ve bütçelenen maliyet kapsamında üretim sürecinin planlanması, yaşam döngüsünün tamamlanmasıdır [2,8-10]. Fakat proje yaşam döngüsünde yer alan aktörlerin birbirinden farklı yetenekleri, kültürü, bilgisi, deneyimi, bireysel/mesleki disiplini, amaç ve hedefleri, beklentileri, algıları, vb. çatışma zemini olabilmekte, inşaat projelerinin başarılarını da etkileyebilmektedir. İnşaat projelerinin başarısında kritik bir öneme sahip olan çatışmanın kontrol edilmesi, yönetilmesinde ilk adım paydaşların çözüm yaklaşımlarının bilinmesidir. Bir inşaat projesinin yaşam döngüsü içinde farklı aşamalarında ortaya çıkabilecek kişiler arası çatışmalar aktörlerin deneyim düzeyi, eğitim altyapıları, kültürel özellikleri, işe karşı tutumları, davranışları, çalışma yöntemleri [9], duygularını ifade biçimleri, alg1 ve inançlarındaki farklılıklar [10] ve olay/durumları algılarındaki farklılıklar, değişiklikler, çelişkiler, vb. birbirinden farklı bireysel özellikleri gibi çatışma nedenleri arasındadir [11-13].

Çatışma yapım yönetim alanında yapılan çalışmalarda sıklıkla incelenen konulardandır. Literatürde yoğun olarak anlaşmazlıkların nedenlerine $[7,14]$, çatışma ortaya çıktığında nasıl çözülebileceğine odaklanıldığı, inşaat sektöründe çatışmanın kaçınılmaz olduğu, etkin olarak yönetiminin önemi vurgulanmaktadır [5]. Bu çalışmada, inşaat proje organizasyonlarında kişiler arası çatışma çözüm yaklaşımları ve kişilik özellikleri ile ilişkisi incelenmiştir. Bunun için Türk inşaat sektöründe rol alan meslek profesyonellerinden mimar ve inşaat mühendislerini kapsayan bir anket çalışması yapılmıştır. Anket çalışmasında katılımcıların çatışma çözüm yaklaşımlarını ölçmek üzere Rahim [15]'in geliştirdiği Örgütsel Çatışma Envanteri (Organizational Conflict Inventory)'den esinlenerek Özarallı [16] tarafından geliştirilen ve Kuşçuluoğlu [17]'nun çalışmasında kullandığı ölçek kullanılmıştır. Kişilik özelliklerinin incelenmesi için ise John ve Srivastava [18]'nın beş faktör kişilik ölçeği kullanılmıştır. Yapılan anket çalışması sonucunda inşaat sektöründe mimarlık/mühendislik ofisi ve yüklenici/tedarikçi firma (şantiye) çalışanı mimar ve inşaat mühendislerinin benimsedikleri çatışma çözüm yaklaşımlarının kişilik özellikleri ile ilişkisi saptanmıştır. Çalışma sonuçlarının inşaat projelerinin ana bileşeni olan insanın etkinliği ve verimliliğini arttırmaya yönelik araştırmalara katkı sunacağ1 düşünülmektedir.

\section{1. Çatışma Çözüm Yaklaşımı}

Çatışma, uyumsuzluk, anlaşmazlık veya sosyal varlıklar (bireyler, gruplar, organizasyonlar, vb.) arasında kendi ihtiyaçlarına veya çıarlarına uygun 
olmayan bir faaliyete katılması gerektiğinde, herkesin isteklerinin tam olarak karşılanamaması, davranışsal tercihlerde bulunması ile ortaya çıkan etkileşimli bir süreçtir [15]. Kumaraswamy [7] çatışmanın bireyler arasında yaşanan inanç, fikir ayrılıkları, anlaşmazlıklar olduğunu ifade etmiştir. Rahim [15] ile Rahim ve Bonoma [19], interaktif bir süreç olarak değerlendirdiği çatışmanın, bireyler/grupların amaç, davranış, inanç, değerleri arasındaki farklılıklardan ortaya çıktığını, bireyler/gruplar içinde veya arasındaki uyumsuzluk olarak kendini gösterdiğini öne sürmüştür. Basım ve arkadaşları [20]'a göre kişiler arası çatışmalar davranışsal, bilişsel, duygusal unsurlar içermekte, karşılıklı bağımlı tarafların hedeflerine ulaşmada müdahale, uyuşmazlık hissetmeleri, engelleme algılamaları sonucunda oluşabilmektedir. Jaffar ve arkadaşları [14] inşaat sektörü özelinde incelediği çatışma nedenlerini davranışsal nedenler, sözleşmeden doğan çatışmalar, teknik problemler olmak üzere üç kategoride değerlendirmiş, kişilerarası çatışmanın bireylerin ihtiyaçları, beklenti, çıkarları, değerleri, kaygıları, inançları, algıları arasındaki farklılıklar gibi birçok nedeni barındırabileceğini öne sürümüştür. Bir başka bakış açısına göre ise, çatışma sosyal ve bireysel değişimin temelinde yatmaktadır, kaçınılmazdır, seçimlere ve bulunulan ortama bağlı olarak etkileme/etkilenmenin sonucudur [20].

Araştırmacılar çatışmanın olumsuz olarak ele alınmasının her zaman doğru olmadığı, iyi yönetilmesi halinde yaratıcı fikirlerin, problem çözümlerinde uyarıcı olabileceği, çalışan performansını arttırabileceğini öne sürmektedir [15,19,21]. Fenn ve arkadaşları [4]'e göre çatışma risk alma, girişim ve rekabet ile ilgili olumlu yönleri bulunmaktadır ve çıkar uyuşmazlığının olduğu her yerde olabilecek bir durumdur.

Çatışmanın yönetilmesi için çatışmanın bireyler tarafından nasıl algılandığı, çatışmanın çözümünde benimsedikleri yaklaşımlar önem kazanmaktadır. Fakat burada üzerinde durulması gereken noktalardan biri, çatışma çözüm yaklaşımlarının bireylerin sabit davranışları olarak algılanmasının yanıltıcı olabileceğidir. Bu nedenle duruma yada ilişkilere göre seçilen bir strateji yada niyet olarak algilanmalıdır [5,22].
Çatışma çözümüne yönelik yapılan çalışmalardan [örn; 21] ilki Follett [23] tarafından yapılmıştır. Follett [23]'a göre organizasyonal çatışmanın üstesinden gelmenin hükmetme, uzlaşma, işbirliği olmak üzere üç yolu bulunmaktadır [19]. Blake ve Mouton [24] ise, kavramsal bir çerçeve çizerek kişilerarası çatışmaların yönetim yaklaşımlarını sınıflamıştır. Blake ve Mouton [24] kişilerarası çatışma çözüm yaklaşımlarını zorlamak, geri çekmek, yumuşatmak, ödün vermek ve problem çözmek olmak üzere beş boyut ile tanımlamıştır [19].

Çatışma sırasında birey kendi endişesini gidermeye çalışabilmekte veya diğer bireyleri kaygılarını giderme isteğiyle yönelimlerini iki temel boyutta farklılaştırmaktadır. [16,19]. Bu iki yönelimin birleşimi sonucu kişiler arası çatışma beș boyut ile ele alınmaktadır [18]. Literatürde Rahim [15] ile Rahim ve Bonoma [19] tarafindan yapılan çalışma yaygın kabul görmektedir. Rahim [15] ile Rahim ve Bonoma [19] çatışma çözüm yaklaşımlarını problem çözme, uzlaşma, zorlama, uyma, kaçınma olmak üzere beş boyut ile sınıflamıştır:

Problem çözme yaklaşımı: Çatışma taraflarının iş birliği [15] içinde bilgi alışverişinde bulunarak her birinin kabul edeceği ortak çözüm yollarını bulmaya yönelik davranışlarıdır [16]. Problem çözebilmek için ise tarafların açık ve doğrudan iletişimi öncelikli gerekliliklerdendir. Bu yaklaşımda da, çatışmanın tarafları arasında iş birliği, birbirine karşı niyetlerinde açıklık ve netlik, bilgi alışverişini içermektedir [15]. Uzlaşma yaklaşımı: Çatışma taraflarının çatışmaya konu olan sorun ile ilgili bir karara varabilmek için karşılıklı olarak kendi çıkarlarından, hedeflerinin bir bölümünden vazgeçerek uzlaşmaya varma davranışıdır [16]. Bireylerin çatışma içinde olduğu karşı tarafın hedeflerinin bir bölümünden vazgeçmeye ikna ederek uzlaşma zemini oluşturma çabasını içermektedir $[16,17]$.

Zorlama yaklaşımı: Bu çözüm yaklaşımı, bireyin karşı tarafla olan ilişkisine önem vermeden kendi çıkarını gözeterek, çıkarları doğrultusunda ne pahasına olursa olsun karşı tarafın çözümü kabul etmesi için zorlama, kendi amacını gerçekleştirmeye çalışma davranışıdır [16]. Birey 
rekabet halinde bulunduğu karşı tarafın ihtiyaç ve beklentilerini önemsemeyerek göz ardı etmesi, kendi hedef ve amaçları doğrultusunda davranış yaklaşımları sergilemesidir [16,19].

Kaçınma yaklaşımı: Bu yaklaşımda birey var olan veya potansiyel çatışmayı fark etmesine rağmen, konuyu/durumu görmezden gelme, erteleme veya kadere boyun eğme, yüzleşmekten kaçınma, geri çekilme davranışı göstermesidir [16,19,25]. Kaçınma yaklaşımı bireyin içinde bulunduğu durumdan daha uygun bir zamana kadar sorumluluğu başkasına yüklemektedir [16,25].

Uyma yaklaşımı: Bu çatışma yaklaşımında birey karşılıklı ilişinin korunması için tavizkar davranışlar göstererek, karşı tarafin isteklerine boyun eğerek kendi hedeflerinden vazgeçmektedir [16]. Bu yaklaşım problem çözme yaklaşımı gibi iş birliğine teşvik etse de dolaylı ve pasif bir uygulamadir [22].

Bazı araştırmacıların [örn; 24, 25] problem çözme yaklaşımının çatışmayı yönetmek için en uygun yaklaşım olduğunu öne sürmelerine rağmen, farklı durumlarda bir yaklaşımın diğerinden daha uygun olabileceği literatürde yer bulmaktadır $[15,19,25]$. Friedmann ve arkadaşları [26], çatışmanın zorlama veya kaçınma yaklaşımıyla çözmeye çalışmanın rol çatışması olasılıklarını yükselttiğini ileri sürmektedir.

\subsection{Kişilik Özellikleri}

Kişilik kavramı, sosyal yaşamın bir parçası olarak insanın sosyal yaşantısının bir parçası olarak yüzyıllar boyunca ilgi görmesine rağmen bilimsel gelişimine 1930'lu y1llarda kişilik psikolojisinin diğer sosyal bilim alanlarından ayrı bir bilimsel disiplin olarak ortaya çıkmasıyla başlamıştır [27]. Bireyin edindikleri deneyimlere dayanan algıları ve davranışları kişilik özeliklerine katkılar sağlamakta, bireyler arasında farklı kişilik yapılarının oluşumunu hazırlamaktadır. Bireyin özel ilgi alanlarından, çevresiyle kurduğu diyaloğa kadar birey ve bulunduğu çevresini etkileyen kişilik kavramı doğuştan gelen ve yaşamın kazandırdığı bedensel, zihinsel ve ruhsal özellikler bütünüdür [28,29].
Kişilik özellikleri bireyden bireye değişkenlik göstermesi ve çeşitlenmesine rağmen liretatürde kişilik özelliklerinin sınıflaması ve kişilik özelliklerinin belirlenmesine yönelik ölçek geliştirme çalışmaları güncelliğini korumaktadır [18].

McCrea ve Costa [30]'nın çalışması, kişilik özelliklerinin beş temel boyut ile ölçülebilmesi için ölçek geliştirmeye yönelik öncü çalışmalardan biridir [31]. McCrea ve Costa [30] geliştirdikleri ölçekte kişilik özelliklerini dişadönüklük, geçimlilik, duygusal dengelilik, sorumluluk, deneyime açılık olmak üzere beş boyut tanımlamıştır.

Dışadönüklük: Bireyin kişiliğinin sosyallik, cana yakınlık düzeyini tanımlamaktadır [32]. Birey kendisine duyduğu güvenle çevresiyle rahat etkileşime girmektedir. Grup çalışmasına yatkın olan dişadönük bireyler girişken, heyecan arayan, atılgandır ve olumlu duygular yaşamaya meyillidirler [32-34].

Geçimlilik: Kişiler arası ilişkilerde rekabetten uzak iş birliğine, uzlaşmaya yatkın olan geçimli bireyler olup sosyal ve güvenilir kişilik özellikleri gösterme eğilimindedir [33,34].

Duygusal Dengelilik: Rahat ve sakin kişilik yapısına sahip bu bireyler iyi stres yönetme becerilerine sahiptirler [32]. Olaylar karşısında duygularını kontrol edebilen, tutarlı tepkiler verebilen bireylerdir [33,34].

Sorumluluk: Genel olarak dikkatli, güvenilir ve sorumluluk sahibi olan bireyler, planlı düzenlidir $[33,34]$.

Deneyime açılık: Entelektüel ilgisi, hayal gücü yüksek bireyler değişime adaptasyonda esnektir [34,35]. Kişilik özellikleri bireyin davranışlarına yansıyan, yönlendiren, bireysel ve organizasyonal ilişkileri etkileyen önemli bir faktördür. Buradan hareketle çatışma çözüm yaklaşımları ile kişilik özellikleri arasındaki ilişki farklı alanlarda araştırmacılar tarafından sıklıkla incelenen araştırma konuları içindedir. 


\section{2. ÖNCEKİ ÇALIŞMALAR}

Basım ve arkadaşları [20] çalışmasında kişiler arası çatışma çözüm yaklaşımlarına etki eden kişilik yaklaşımlarını incelemiştir. Çatışma çözüm yaklaşımları ölçeği ve beş faktör kişilik özellikleri ölçeğini kullanılmıştır. Araştırmanın sonuçları, gelişime açıklık ve uyumluluk kişilik özelliklerinin, tüm çatışma çözme yaklaşımları ile ilişkisi olduğunu göstermektedir. Ayrıca dışadönüklük ve özdisiplin kişilik özellikleri çatışma çözüm süreçlerinde önemli rol oynadığını vurgulanan çalışmada nörotiklik (duygusal dengelilik) kişilik özelliği ile çatışma çözme yaklaşımları arasında ilişki ortaya konulmuştur.

Göktekin [35] çalışmasında inşaat sektöründe çatışmaların tanımlanmasını, nedenlerinin ortaya konulmasını ve çatışma yönetim biçimlerinin saptanmasını amaçlamıştır. İnşaat sektöründe verimlilik, işgücü ve kaynak kaybına neden olan proje süreçlerinin uzaması veya durmasıyla sonuçlanabilecek çatışma çözüm yaklaşımlarının önemini vurgulamıştır. Yapılan çalışmada Türkiye'de inşaat firmalarında çalışanların çalışma giderim biçimlerinin saptanabilmesi için Rahim'in geliştirdiği çatışma çözüm yaklaşımı ölçeğinin kullanıldığı alan çalışması yapılmıştır. Sonuçlar, inşaat çalışanlarının yüksek oranda problem çözme çözüm biçimini tercih ettiğini göstermiştir.

Balcı [9] çalışmasında, Türk inşaat sektöründe faaliyet gösteren genel yüklenici firmada çalışanların çatışma çözüm yaklaşımlarının belirlenmesini amaçlamıştır. Çalışma kapsamında uluslararası havaalanı projesinde çalışanların çatışma çözüm yaklaşımlarının katılımcıların demografik değişkenleri ve kültürün alt başlıkları olan bağımlı/bağımsız benlik kurgusu arasındaki ilişki incelenmiştir. Çatışma çözüm yaklaşımlarının belirlenmesi için Rahim tarafından geliştirilen ölçek kullanılmıştır. Sonuçlar, katılımcıların çoğunlukla çatışma giderim biçimlerinden işbirliğine yöneldiği, bağımsızlık eğilimi gösteren kişilerin çatışma giderim biçimi ağırlıklı olarak zorlama yaklaşımını tercih etiği, bağımlılık gösteren kişilerin çatışma giderim yaklaşımının kaçınma olduğu yönündedir.
Gül ve Acar [36] çalışmasında, büyük ve orta ölçekli inşaat firmalarının yurtiçi/yurtdışı pazarda karşılaştıkları uyuşmazlık konuları ve karşılaşma sıklıklarını incelemiş, en sık kullanılan uyuşmazlık çözüm yaklaşımlarını ortaya koymuştur. Araştırma bulguları, yüklenici firmaların haklara, güce dayalı çatışma çözüm yaklaşımları benimsedikleri yönündedir.

Genç [37], çalışmasında inşaat projelerinde çalışan mimar ve mühendislerin çatışma nedenleri ve çatışmanın boyutlarını incelemiştir. Çalışma kapsamında yapılan anket çalışması 142 katılımcı ile gerçekleştirilmiştir. Sonuçlar, inşaat projelerinde en sık yaşanan çatışmaların proje bölümü ve saha uygulamaları arasında olduğu tespit edilmiştir. Bunu planlama ve saha uygulamaları bölümlerinin izlediğini ortaya koymuştur.

Jaffar ve arkadaşları [14], çalışmasında, çatışmanın inşaat projeleriyle eş anlamlı görüldüğünü, proje maliyetlerinin artması, proje gecikmeleri, verimin düşmesi, elde edilen karın düşmesi, iş iliş̧kilerinin bozulmasının bir yansıması olabileceğini öne sürmektedir. Çalışmada çatışma kaynakları davranış problemleri, sözleşme problemleri ve teknik problemler olmak üzere üç başlık altında incelenmiştir. Davranışsal faktörlerden kaynaklanan çatışma faktörleri, proje takımında yapıcılık, netlik ve bütünlük ve zayıf iletişimi kontrol etmek konusunda isteksizdir. Sözleşmeden doğan sorunları, geç teslim alma, müşteriden geçici ödemenin gecikmesi ve sözleşmeden doğan sözleşmelerin netleşmemesidir. Yüklenici, mimar veya mühendisden gelen talimatların gecikmesi teknik sorunlar nedeniyle ortaya çıkan çatışma faktörleridir.

Lu ve Wang [38] çalışmasında, inşaat sektöründe mal sahipleri ve sözleşmeciler arasındaki ilişkinin proje performansında etkili bir faktör olduğunu ileri sürüdüğü çalışmasında çatışma yönetim yaklaşımları ve ilişki kalitesi arasındaki ilişkiyi incelemiştir. İnşaat sektöründe 165 mal sahibi ve sözleşmeci ile gerçekleştirdiği anket çalışmasında sonuçlar bütünleştirici yaklaşım, ilişki kalitesi ile pozitif ilişkiliyken, ödün vermeyen yaklaşım negatif ilişkili bulunmuştur. 
Tabassi ve arkadaşları [39] çalışmasında, Malezya inşaat sektöründe çok kültürlü çalışma ortamında takım liderlerinin çatışma çözüm yaklaşımlarını incelediği çalışmasında iş birliğinin takım performansı ve takım koordinasyonunda olumlu etkisinin olduğunu ileri sürmüştür.

Zhang ve arkadaşları [40], duygusal zekâ, çatışma yönetim yaklaşımı ve yenilik performansı arasındaki ilişkiyi incelemiştir. Çalışma sonuçları duygusal zekanın yenilik performansının yanı sıra bütünleştirme, ödün verme ve baskın olma yaklaşımları ile pozitif anlamlı bir ilişkisinin olduğu yönündedir. Ayrıca duygusal zekâ ile yenilik performansı arasındaki ilişki üzerinde aracılık etkisinin olduğunu öne sürmüştür.

Wu ve arkadaşları [41], Çin inşaat sektöründe organizasyonlar arası çatılmanın çatışmanın proje üzerindeki etkisini ve çatışma yönetim stratejileri arasındaki ilişki araştırılmıştır. Araştırma sonuçlarına göre; görev çatışması, ilişki çatışması ve süreç çatışması proje paydaşlarının karakteristik özelliklerinden, ikili ilişkilerden, projenin içerik özelliğinden etkilenmektedir.

Maiti ve Choi [42], Çatışmalar organizasyonun kaçınılmaz bir parçasıdır ancak önemli olan organizasyonun çatışmaların nedenini belirlemesi ve onları yönetmesidir. $\mathrm{Bu}$ çalışma, inşaat sektöründeki çatışmaları en aza indirgemek için çatışma yönetimi stratejilerinin uygulanmasını araştırmayı amaçlamaktadır. Literatür taraması ve 80 inşaat uzmanından veri elde etmek için bir anket çalışması da dahil olmak üzere metodolojik üçgenleme uygulanmıştır. Sonuçlar, çalışanların farkındalığının inşaat endüstrisindeki en büyük çatışma nedeni olduğunu ortaya çıkarırken, sendika yönetimi çatışmasının en büyük çatışma türü olduğu ortaya çıktı. Toplu pazarlık stratejisinin çatışmayı yönetmede daha etkili olduğu bulundu. Organizasyon performansı ile çatışma yönetimi teknikleri arasındaki korelasyon katsayısı analizi, organizasyonal performans ile uzlaşma, toplu pazarlık ve konaklama gibi çatışma yönetimi stratejileri arasında pozitif bir ilişki olduğunu gösterirken, diğer stratejilerin organizasyonal performans üzerinde olumsuz bir etkisi olduğunu göstermektedir.

\section{MATERYAL VE METOT}

Çalışmanın örneklemini Türk inşaat sektöründe mimarlık/mühendislik ofisinde ve yüklenici/ tedarikçi firma (şantiye) çalışan mimar ve inşaat mühendisleri oluşturmaktadır. Kişiler arası çözüm yaklaşımları Anket çalışması yardımıyla toplanan 254 adet anket değerlendirmeye alınmıştır.

İnşaat proje organizasyonlarında rol alan meslek profesyonellerinden mimar ve inşaat mühendislerinin çatışma çözüm yaklaşımlarının kişilik özellikleri ile ilişkisini ölçmek için bir anket formu geliştirilmiştir. Veri toplamak amacıyla hazırlanan anket formunda katılımciların demografik özellikleri, beş faktör kişilik ölçeği, çatışma çözüm yaklaşımı ölçeğini içermektedir. Anketin demografik özellikler ile ilgili bölümünde katılımcıların cinsiyeti, yaşı, eğitim durumu, mesleki tecrübeleri, kurumsal faaliyet alanları, mesleklerine ilişkin veri toplamak amaciyla geliştirilen sorular yer almaktadır. Anketin sonraki bölümünde kişilik özellikleri için beş faktör kişilik ölçeği yer almaktadır. John ve Srivastava [18] tarafından geliştirilen beş faktör kişilik ölçeği kullanılmıştır. Beş faktör kişilik ölçeği dışadönüklük, geçimlilik, dengelilik, sorumluluk ve deneyime açıklık kişilik özelliklerini beş faktörle açıklamaktadır. Çalışmada katılımcıların çatışma çözüm yaklaşımlarını ölçmek için Rahim [15] tarafından bireyler, grup ve gruplar arası çatışmayı ele alan beş yaklaşımın ölçülmesi için geliştirdiği ölçekten yararlanılarak Özarallı [16]'nın Türk çalışanlarına yönelik geliştirdiği, 25 ifadeden oluşan ölçek kullanılmıştır. Ölçekte katılımcılara çalışma ortamında yaşadıklarında çatışmaları çözmek için hangi davranışları gösterdiklerine ilişkin ifadeler yer almaktadır. Anket formunda yer alan soru/ifadelere ne derece (1=Hiç Katılmıyorum, 5=Tamamen Katılıyorum) katıldıkları sorulmuştur. Elde edilen verilerin analizi SPSS 22 programı ile gerçekleştirilmiştir.

\section{BULGULAR VE TARTIŞMA}

Katılımcıların demografik özellikleri Çizelge 1'de verilmiştir. Bulgular katılımcıların \%47'sininin 
kadın, \%53'ünün erkek olduğunu göstermektedir. Katılımcılar ağırlıklı olarak 17-26 yaş aralığında (\%39) ve lisans düzeyinde $(\% 85)$ eğitim düzeyine sahiptir. Katılımcıların \%4'si 1-4 yıl, \%28'i 5-9 y1l, \%6's1 10-12, \%7'si 13-15, \%6's1 ise 16- üstü mesleki tecrübeye sahiptir. Kurumsal faaliyet alanları ise \% 62 mimarlık/mühendislik ofisi, \%38 şantiye (yüklenici/tedarikçi firma)'dir. Katılımcıların \%54'ünü mimarlar oluştururken, \%46'sı inşaat mühendislerinden oluşmaktadır (Çizelge 1).

Çizelge 1. Katılımcıların demografik özellikleri

\begin{tabular}{|c|c|c|}
\hline & Frekans & $\begin{array}{c}\text { Yüzde } \\
(\%)\end{array}$ \\
\hline \multicolumn{3}{|l|}{ Cinsiyet } \\
\hline Kadın & 120 & 47 \\
\hline Erkek & 134 & 53 \\
\hline \multicolumn{3}{|l|}{ Yaş } \\
\hline $17-26$ & 100 & 39 \\
\hline $27-36$ & 99 & 39 \\
\hline $37-46$ & 41 & 16 \\
\hline 47-üstü & 14 & 6 \\
\hline \multicolumn{3}{|l|}{ Eğitim Durumu } \\
\hline Lisans & 217 & 85 \\
\hline Yüksek lisans/Doktora & 37 & 15 \\
\hline \multicolumn{3}{|l|}{ Mesleki Tecrübe } \\
\hline $1-4$ & 107 & 42 \\
\hline $5-9$ & 72 & 28 \\
\hline $10-12$ & 16 & 6 \\
\hline $13-15$ & 17 & 7 \\
\hline 16-üstü & 42 & 7 \\
\hline \multicolumn{3}{|l|}{ Kurumsal Faaliyet } \\
\hline $\begin{array}{l}\text { Mimarlık/Mühendislik } \\
\text { Ofisi }\end{array}$ & 158 & 62 \\
\hline $\begin{array}{l}\text { Yüklenici/Tedarikçi Firma } \\
\text { (şantiye) }\end{array}$ & 96 & 38 \\
\hline \multicolumn{3}{|l|}{ Meslek } \\
\hline Mimar & 136 & 54 \\
\hline İnşaat Mühendisi & 118 & 46 \\
\hline
\end{tabular}

\subsection{Kullanılan Ölçeklerin Güvenilirlikleri}

Çatışma çözüm yaklaşımı ölçeği Özarallı [16] çalışmasında 5 boyutlu ölçeğin faktör analizi sonucunda uzlaşma ve problem çözme boyutlarının aynı faktör altında toplanmıştır. Türk çalışanlarının bu iki boyutu tek bir boyut gibi algıladıklarını öne sürmüştür. Benzer bir sonuç Altıntaş [43]'ın çalışmasında yer almaktadır. Bu çalışmada da bu durumun tekrarlanıp tekrarlanmadığını incelemek amacıyla çatışma çözüm yaklaşımı ölçeği için faktör analiz uygulanmıştır. Faktör analizi sonuçları Çizelge 2'de verilmiştir. Analiz sonuçları Çatışma çözüm yaklaşımı ölçeği ne ilişkin ifadeleri 5 boyut ile algıladığı görülmüștür.

Çizelge 2. Çatışma çözüm yaklaşımları faktör analizi

\begin{tabular}{|c|c|c|}
\hline & Madde & Faktör yükleri \\
\hline \multirow{6}{*}{$\begin{array}{l}\text { Faktör } 1 \\
\text { Problem çözme }\end{array}$} & Madde 22 & 0,657 \\
\hline & Madde 4 & 0,688 \\
\hline & Madde 14 & 0,724 \\
\hline & Madde 19 & 0,678 \\
\hline & Madde 12 & 0,705 \\
\hline & Madde 17 & 0,592 \\
\hline \multirow{3}{*}{$\begin{array}{l}\text { Faktör } 2 \\
\text { Uzlaşma }\end{array}$} & Madde 9 & 0,500 \\
\hline & Madde 3 & 0,672 \\
\hline & Madde 24 & 0,654 \\
\hline \multirow{5}{*}{$\begin{array}{l}\text { Faktör } 3 \\
\text { Zorlama }\end{array}$} & Madde 16 & 0,596 \\
\hline & Madde 6 & 0,771 \\
\hline & Madde 11 & 0,826 \\
\hline & Madde 21 & 0,819 \\
\hline & Madde 1 & 0,766 \\
\hline \multirow{5}{*}{$\begin{array}{l}\text { Faktör } 4 \\
\text { Kaçınma }\end{array}$} & Madde 25 & 0,662 \\
\hline & Madde 15 & 0,769 \\
\hline & Madde 20 & 0,670 \\
\hline & Madde 10 & 0,432 \\
\hline & Madde 5 & 0,447 \\
\hline \multirow{5}{*}{$\begin{array}{l}\text { Faktör } 5 \\
\text { Uyma }\end{array}$} & Madde 13 & 0,795 \\
\hline & Madde 8 & 0,749 \\
\hline & Madde 18 & 0,647 \\
\hline & Madde 3 & 0,686 \\
\hline & Madde 24 & 0,636 \\
\hline
\end{tabular}

Çalışmada kullanılan ölçeklerin güvenilirlikleri Cronbach Alpha $(\alpha)$ katsayıları hesaplanarak incelenmiştir. Çatışma çözüm yaklaşımları ölçeği, kişilik özellikleri ölçeği ve alt boyutlarına ilişkin elde edilen Cronbach Alpha $(\alpha)$ değerleri Çizelge 3'de verilmiştir. Cronbach Alpha ( $\alpha)$ değerlerinin yorumlanasında güvenilirlik katsayılarına ilişkin değerler aşağıda verilmiştir.

$0,00 \leq \alpha \leq 0,40$ değerleri arasında ölçek güvenilir değildir,

$0,40 \leq \alpha \leq 0,60$ değerleri arasında ölçeğin güvenirliliği düşüktür, 
$0,60 \leq \alpha \leq 0,80$ değerleri arasında ölçek oldukça güvenilirdir,

$0,80 \leq \alpha \leq 1,00$ değerleri arasında ise ölçek yüksek derecede güvenilirdir [44, Akt., 45].

Bu durumda kişilik özellikleri $(\alpha=0,851)$ ve çatışma çözüm yaklaşımları $(\alpha=0,809)$ ölçeği için $\alpha$ değerleri yüksek derecede güvenilirdir. Yanı sıra deneyime açıklık $(\alpha=0,810)$, zorlama $(\alpha=0,842)$ ve uyma $(\alpha=0,818)$ boyutları için hesaplanan $\alpha$ değerleri yüksek derece güvenilirdir. Ayrıca dışadönüklük $(\alpha=0,717)$, geçimlilik $(\alpha=0,608)$, sorumluluk $(\alpha=0,666)$, dengelilik $(\alpha=0,702)$, problem çözme $(\alpha=0,776)$, kaçınma $(\alpha=0,784)$ boyutlarına ilişkin $\alpha$ değerleri oldukça güvenilirdir. Fakat uzlaşma $(\alpha=0,555)$ boyutuna ilişkin güvenilirlik değeri düşüktür. Bunun nedeni uzlaşma boyutunun az sayıda soru (3 soru) ile ölçüm yapılmasına bağlı olabilir [46].

Çizelge 3. Ankette kullanılan ölçeklerin soru sayıları, ortalamaları ve güvenilirlikleri

\begin{tabular}{|l|c|c|}
\hline Anket & $\begin{array}{c}\text { Ortalama } \\
(\mu)\end{array}$ & $\begin{array}{c}\text { Güvenilirlik } \\
(\alpha)\end{array}$ \\
\hline Kişilik özellikleri & $\mathbf{3 , 8 3 9}$ & $\mathbf{0 , 8 5 1}$ \\
\hline Dişadönüklük & 3,699 & 0,717 \\
\hline Geçimlilik & 3,956 & 0,608 \\
\hline Dengelilik & 3,332 & 0,702 \\
\hline Sorumluluk & 3,898 & 0,666 \\
\hline Deneyime açılık & 3,916 & 0,810 \\
\hline $\begin{array}{l}\text { Çatışma çözümü } \\
\text { yaklaşımları }\end{array}$ & $\mathbf{3 , 1 0 7}$ & $\mathbf{0 , 8 0 9}$ \\
\hline Problem çözme & 4,249 & 0,776 \\
\hline Uzlaşma & 4,357 & 0,557 \\
\hline Zorlama & 2,592 & 0,842 \\
\hline Kaçınma & 2,379 & 0,784 \\
\hline Uyma & 2,486 & 0,818 \\
\hline
\end{tabular}

Çizelge 3'deki kişilik özelliklerine ilişkin ortalamalar değerlendirildiğinde, bulgular katılımcıların yüksek düzeyde dişadönük $(\mu=3,839)$, geçimli $(\mu=3,956)$, sorumluluk sahibi $(\mu=3,898)$ ve deneyime açık $(\mu=3,916)$ bireyler olduklarını göstermektedir. Elde edilen bulgular katılımcıların orta düzeyde dengeli $(\mu=3,332)$ bireyler oldukları yönündedir.
Çatışma çözüm yaklarına ilişkin bulgular değerlendirildiğinde ise; katılımcıların yüksek düzeyde problem çözme $(\mu=4,296)$, uzlaşma $(\mu=4,357)$ yaklaşımlarını benimsedikleri, zorlama $(\mu=2,592)$, kaçınma $(\mu=2,379)$, uyma $(\mu=2,486)$ yaklaşımlarını ise düşük düzeyde uyguladıkları görülmektedir (Şekil 1).

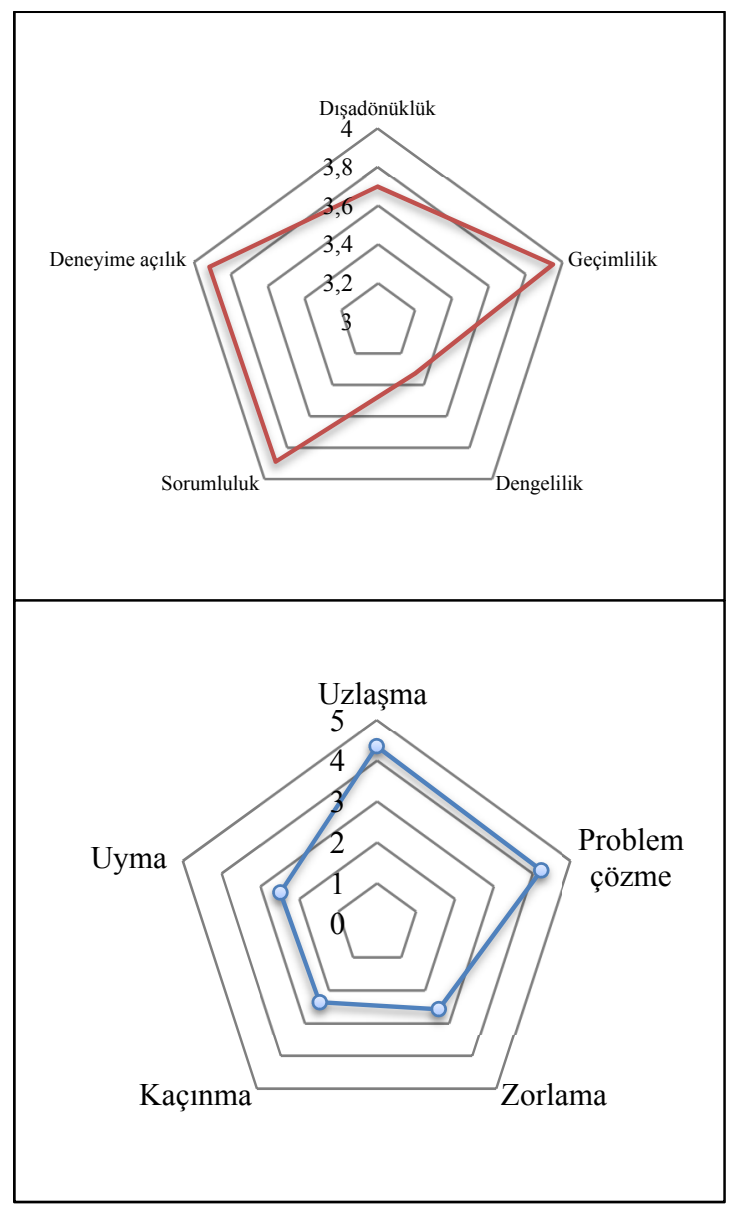

Şekil 1. Katılımcıların çatışma çözüm yaklaşımları ve kișilik özellikleri

Değişkenler arası ilişkileri incelemek amacıyla korelasyon analizi yapılmıştır. Analiz sonuçları incelendiğinde bulgular problem çözme ile sorumluluk $(r=0,261 ; p \leq 0,01)$, geçimlilik $(r=0,382$; $\mathrm{p} \leq 0,001)$, deneyime açılık ( $\mathrm{r}=0,295 ; \mathrm{p} \leq 0,001)$ arasında pozitif anlamlı bir ilişkinin olduğunu göstermektedir. Ayrıca çatışma çözüm yaklaşımlarından uzlaşma boyutu ile geçimlilik 
$(\mathrm{r}=0,313 ; \mathrm{p} \leq 0,001)$, deneyime açıklık ( $\mathrm{r}=0,301$; $\mathrm{p} \leq 0,001)$ ve sorumluluk $(\mathrm{r}=0,246 ; \mathrm{p} \leq 0,001)$ kişilik özellikleri ile arasında pozitif anlamlı bir ilişki bulunmuştur. $\mathrm{Bu}$ bulgular; işbirliğine yatkın, sorumluluk sahibi sosyal, entelektüel birikimi ve hayal gücü yüksek bireylerin çatışma durumunda problem çözme ve uzlaşma gibi işbirliğine açık ve her iki tarafın çıkarlarına uygun çözüm arayışında oldukları yönündedir.

Elde edilen bulgular zorlama ile deneyime açıklık $(\mathrm{r}=-0,177 ; \quad \mathrm{p} \leq 0,001), \quad$ geçimlilik $\quad(\mathrm{r}=-0,307$; $\mathrm{p} \leq 0,001)$, duygusal denge $(\mathrm{r}=-0,208 ; \mathrm{p} \leq 0,001)$, sorumluluk $(\mathrm{r}=-0,226 ; \mathrm{p} \leq 0,001)$, geçimlilik $(\mathrm{r}=$ $0,307 ; \mathrm{p} \leq 0,001)$, deneyime açılı $1 \mathrm{k} \quad(\mathrm{r}=-0,177$; $\mathrm{p} \leq 0,001)$; kaçınma ile dışadönüklük ( $\mathrm{r}=-0,207$; $\leq 0,001)$, sorumluluk $(\mathrm{r}=-0,176 ; \leq 0,001)$, geçimlilik $(\mathrm{r}=-0,227 ; \leq 0,001)$ negatif anlamlı ilişkinin var olduğunu göstermektedir. Araştırma bulgularında çatışma çözüm yaklaşımlarından uyma boyutunun herhangi bir kişilik özelliği ile anlamlı ilişkisi elde edilememiştir (Çizelge 4). $\mathrm{Bu}$ bulgular doğrultusunda; çatışma durumunda karşı tarafla ilişkisini önemsemeyerek kendi amaçları doğrultusunda yaklaşımlar gösteren veya çatışma ile yüzleşmeden kaçınma davranış yaklaşımları gösteren bireylerin değişime adaptasyonda zorlanan, rekabetçi, sorumluluk almaktan kaçınan bireysel özellikler göstermektedir.

Çizelge 4. Korelasyon analizi

\begin{tabular}{|c|c|c|c|c|c|c|}
\hline & \multicolumn{5}{|c|}{ Kişilik Özellikleri } \\
\hline & & Dışadönüklük & $\begin{array}{c}\text { Duygusal } \\
\text { Denge }\end{array}$ & Sorumluluk & Geçimlilik & $\begin{array}{c}\text { Deneyime } \\
\text { Açıklık }\end{array}$ \\
\hline \multirow{10}{*}{ 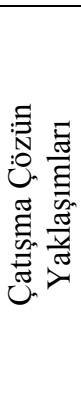 } & \multirow{2}{*}{$\begin{array}{l}\text { Problem } \\
\text { çözme }\end{array}$} & 0,115 & 0,014 & $0,261 * * *$ & $0,382 * * *$ & $0,295 * * *$ \\
\hline & & 0,069 & 0,823 & 0,000 & 0,000 & 0,000 \\
\hline & \multirow{2}{*}{ Uzlaşma } & 0,500 & 0,046 & $0,246 * * *$ & $0,313 * * *$ & $0,301 * * *$ \\
\hline & & 0,431 & 0,471 & 0,000 & 0,000 & 0,000 \\
\hline & \multirow{2}{*}{ Zorlama } & $-0,031$ & $-0,208 * * *$ & $-0,226 * * *$ & $-0,307 * * *$ & $-0,177 *$ \\
\hline & & 0,625 & 0,001 & 0,000 & 0,000 & 0,005 \\
\hline & \multirow{2}{*}{ Kaçınma } & $-0,207 * * *$ & $-0,114$ & $-0,176^{*}$ & $-0,227 * * *$ & $-0,145 *$ \\
\hline & & 0,001 & 0,072 & 0,005 & 0,000 & 0,022 \\
\hline & \multirow{2}{*}{ Uyma } & $-0,068$ & $-0,162 * *$ & $-0,169 *$ & $-0,049$ & $-0,119$ \\
\hline & & 0,285 & 0,010 & 0,007 & 0,442 & 0,061 \\
\hline
\end{tabular}

$\mathrm{p}^{* * *} \leq 0,001 ; \mathrm{p} * * \leq 0,01 ; \mathrm{p}^{*} \leq 0,05$

\section{SONUÇLAR}

İnşaat sektörü için önemli bir bileşen olan "insan" faktörü inşaat projelerinin yaşam döngüsü içinde proje başarısında önemlidir. Farklı bireysel özelliklere sahip bireylerin amaç ve hedefleri doğrultusunda belirli bir süre için bir araya gelerek hayata geçirdiği proje organizasyonlarında çatışma yaşanması kaçınılmazdır. Ortaya çıkan çatışmaların yönetiminde uygun yöntemlerin kullanılmaması halinde proje maliyetlerinin yükselmesi, sürelerinin uzaması, işçilik, ürün, vb. kalite kayıplarına kadar uzanan olumsuzluklar yaşanabilmektedir. Çeşitli faktörlere bağlı olarak ortaya çıkan çatışmaların çözüm yaklaşımları farklı bireysel özelliklerle değişebilmektedir.
$\mathrm{Bu}$ çalışmada inşaat sektöründe proje organizasyonlarında çalışma ortamında paydaşların kişilik özelliklerinin çatışma çözüm yaklaşımlarında önemli bir bileşen olarak değerlendirilmiş, bireysel özelliklerinin çatışma çözüm yaklaşımları ile ilişkisinin araştırılması amacıyla ele alınmıştır. Elde edilen bulgular, bireylerin çatışma çözüm yaklaşımları benimsemesinde kişilik özelliklerinin önemli rol oynadığını ortaya koymaktadır. Yapılan çalışmalar [örn; 14,19] kişilik özellikleri ile çatışma çözüm yaklaşımları arasında anlamlı ilişkinin olduğunu desteklemektedir. Çalışmada kullanılan ölçeklerin güvenilir bulunması ölçeklerin örneklem grubu tarafından anlaşıldığını göstermektedir. Çalışmada çatışma çözüm yaklaşımları ölçeği için yapılan faktör analizi mimar ve inşaat mühendislerinin 
Rahim [15] tarafından geliştirilen, Özarallı [16] tarafından Türkçeye çevrilerek Türk çalışanlarına uyarlanan ölçekte problem çözme ve uzlaşma iki boyutun tek bir boyut gibi algılandığı yönündeki bulgu bu çalışmada çatışma çözüm yaklaşımlarının beş boyut olarak elde edilmiştir. Bu durum "problem çözme" ve "uzlaşma" boyutlarının bu çalışmanın örneklemi olan ofis ve şantiyede çalışan mimar ve inşaat mühendislerden oluşan katılımcı grubu tarafından farklı boyutlar olarak algılandığını göstermektedir. Çalışmanın kişilik özellikleri ile ilgili bulguları, örneklemde yer alan mimar ve inşaat mühendislerinin dişadönük, sorumluluk sahibi ve deneyime açık kişilik özellikleri gösteren bireyler olduklarını göstermektedir. Çelik ve Oral [34] tarafından yapılan çalışmada benzer sonuçlar ortaya konulmuştur.

Araştırma bulguları mimar ve inşaat mühendislerinden oluşan örneklem grubunun en fazla problem çözme ve uzlaşma çatışma çözüm yaklaşımlarını benimsediklerini göstermektedir. Göktekin [35] çalışmasında benzer sonuçlar elde etmiş, inşaat çalışanlarının yüksek oranda problem çözme çözüm biçimini tercih ettiğini ileri sürmüştür. Bulgulara göre, çatışma yaşayan mimar ve inşaat mühendislerinin kendi çıkarlarının bir bölümünden vazgeçip karşı tarafla anlaşmaya varma yaklaşımı sergilemektedir. Genel olarak dikkatli, güvenilir, sorumluluk sahibi olan planlı ve düzenli rekabetten uzak işbirliğine ve değişime yatkın kişilik özelliklerine sahip örneklem grubunun yüzleşeme gerektiren, etkin yaklaşımlar benimsedikleri görülmektedir.

Elde edilen bulgular, mimar ve inşaat mühendislerinin inşaat projelerinin organizasyonunda kişilik özelliklerinin çatışma çözüm yaklaşımlarının önemli etken olduğu ortaya koymaktadır. Çalışma bulgularının inşaat sektöründe ana bileşen olan insanın etkinliğini ve verimliliğini arttırmaya yönelik çalışmalara katkı sunacağı, bundan sonra yapılacak çalışmalar için zemin oluşturacağı düşünülmektedir.

Bu çalışmada elde edilen bulgular örneklem ile sınırlıdır. Örneklemin proje organizasyonunda rol alan diğer paydaşları (mal sahipleri, yükleniciler, vb.) kapsayacak şekilde genişletilmesiyle değerlendirilmesi daha kapsamlı sonuçlar elde edilebilecektir. Ayrıca çalışma kapsamında temel odak mimar ve inşaat mühendisleridir. Farklı çalışma alanlarında faaliyet gösteren bu meslek profesyonellerinin çalışma ortamlarına (şantiye, ofis, kamu, eğitim kurumları, vb.) özel koşulların ortaya konularak araştırmalar yapılmasıyla öznel sonuçlar elde edilebilir.

Çalışmada çatışma çözüm yaklaşımlarıyla kişilik özellikleri arasındaki ilişkiye yoğunlaşılmıştır. Bundan sonraki çalışmalarda çatışma çözüm yaklaşımlarının açıklama gücünü arttırabilecek cinsiyet, yaş, kurumsal faaliyet, vb. faktörlerle birlikte ele alınması ile daha geniş kapsamlı sonuçlara ulaşılabilecektir.

\section{KAYNAKLAR}

1. Çam, O., Akgün, E., 2007. Kișilerarası çatışma Yönetimi, Ege Üniversitesi Hemşirelik Yüksek Okulu Dergisi, 23(2), 207-221.

2. Çakmak, F.P., 2016. Causes of Disputes in the Turkish Construction Industry Case of Public Sector Projects, AZ ITU Journal of the Faculty of Achitecture, 13(3), 109-118.

3. Ergen, E., Genç, M.İ., Uzunçarşılı Ü., 2009. İnşaat Projelerinde Örgüt İçi Çatışmanın Nedenlerinin ve Boyutlarının Belirlenmesi, 5. Yap1 İşletmesi/Yapım Yönetimi Kongresi, 22-23 Ekim, 317-327.

4. Fenn, P., 1997. Conflict and Dispute in Construction, Construction Management and Ekonomics, 15(6), 513-518.

5. Loosemore, M., Galea N., 2007. Genderlect and Conflict in the Australian Construction Industry, Construction Management and Economics, 26, 125-135.

6. Kale, S., 1994. Conflicts in the construction Project in Turkey: Client, Designer and Contractor Interface, Hariot-Watt University Depertment of Building, Yüksek Lisans Tezi, Edinburg.

7. Kumarasway M.M., 1997. Conflic, Claims and Disputes in Construction Engineering, Construction and Architectural Management, 4(2), 95-111. 
8. Çakmak, E., Çakmak, P.I., 2014. An Analysis of Causes of Disputes in the Construction Industry Using Analytical Network Process, Procedia, Social and Behavioral Sciences, 109 (88), 183-187.

9. Balcı, D. 2010. İnşaat Sektörü Çalışanlarının Çatışma Giderim Yaklaşımları Üzerine Bir Araştırma. Yüksek Lisans Tezi, İstanbul Teknik Üniversitesi, İstanbul.

10. İlban, T., 2008, İnşaat Sektöründe Çatışma Yönetiminin Kültürel Boyutu., Yüksek Lisans Tezi, İstanbul Teknik Üniversitesi, İstanbul.

11. Cheung, S., Suen H.C.H., 2002. A MultiAttributte Utility Model for Dispute Resolution Strategy Selection, Construction Management and Economics, 20, 557-568.

12. Jehn K. A., Mannix E. A. 2001. The Dynamic Nature of Conflict: A Longitudinal Study of Intragoup Conflict and Group Performance, Academy of Management Journal, 44(2), 238-251.

13. Fawzy, S.A., El-Adaway, I.H., 2012. Contact Administration Guidelines for Managing Conflicts, Claims and Disputes under Work Bank-Funded Projects, Journal of Legal Affairs and Dispute Resolution in Engineering and Construction, 4(4), 101-110.

14. Jaffar, N., Abdul A.H., Tharim M.N., 2011. Factors of Conflict in Construction Industry, a Literature Rewiev Procedia Engineering, 20, 193-202.

15. Rahim, M.A., 2002. Toward a Theory of Managing Organizational Conflict, the International Journal Conflict Management, 13(3), 206-235.

16. Özarallı, N., 2015. Örgüt Kültürü ve İșe İlișkin Duygusal İyilik Algısının Çalışanların Çatışma Çözümü Tarzları Üzerindeki Etkisi, İşletme Araştrmaları Dergisi, 7(2), 7-37.

17. Kuşculuoğlu, S., 2004. A Study on Conflict Management Styles in Relation to the Dominant Personality Factors, Marmara Üniversitesi Sosyal Bilimler Enstitüsü, İşletme Anabilim Dalı Yüksek Lisans Tezi, İstanbul.

18. John, O.P., Srivastava S., 1999. The Big-five Trait Taxonomy: History, Measurement and Theorical Perspective. Handbook of Personality: Theory and Research, 2, 102-138.
19. Rahim, M.A., Bonoma, T.V., 1979. Managing Organizational Conflict: A Model for Diagosis and Intervention, Psychological Reports, 44, 1323-1344.

20. Basım, H.N., Çetin F., Tabak A., 2009. Beş Faktör Kişilik Özelliklerinin Kişilerarası Çatışma Çözüme Yaklaşımlarıyla İlişkisi, Türk Psikoloji Dergisi 24(63), 24-34.

21. Chen, M.N., 2006. Understanding the Benefits and Detriments of Conflict on Team Creavity Proces, Creavity and Innovation Management, 15(1), 105-116.

22. Knapp, M.L., Putman, L.L., Davis, L.L., 1998. Measuring Interpersonal Conflict in Organizations: Where so we Go from here?, Management Communication Quarterly, 3, 414-429.

23. Follett, M. P., 1940. Constructive Conflict., H. C. Metcalf \& L. Urwick (Eds.), Dynamic Administration: The Collected Papers of Mary Parker Follett, 30-49. New York, N.Y.: Harper \& Row.

24.Blake, R.R., Mouton, J.S., 1964. Themanagerial Grid: Key Orientations for Achieving Production thoogh People. Houston, Texas: Gulf Publishing Conpany.

25. Rahim, M.A., Psenicka C., 2002. Model of Emotional Intelligence and Conflict Management Strategies: A Study in Seven Contries. International Journal of Organizational Analyisis, 10(4), 302-326.

26. Friedmen, R.A., Currall S.C., Tsai J.C. 2000. What Goes Around Comes Around: the Impact of Personel Conflict and Stress, the International Journal of Conflict Management, 11(1), 32-55.

27. Yelboğa, A., 2006. Kişilik Özellikleri ve İş Performansı Arasındaki İlişkinin İncelenmesi, İş, Güç, Endüstri İlişskileri ve İnsan Kaynakları Dergisi, 8(2), 196-217.

28. Cüceloğlu, D., 1999. İnsan ve Davranış1: Psikolojinin Temel Kavramları, Remzi Kitabevi, 9. Basım, İstanbul.

29. Soysal, A., 2008. Çalışma Yaşamında Kişilik Tipleri: Bir Literatür Taraması, Çimento İşveren Dergisi, 22(1), 5-19.

30. Mc Crea, R.R., Costa, P.T., 1986. Clinical Assesment can Benefit from Recent Advances in the Personality Psycologist, 41, 1001-1003. 
31. Kavas, E., 2016. Stress Coping Attidutes Based on Perceived Religiousness and Received, Religious Education Psychology, 7, 382-398.

32. Horzum, M.B., Ayas T., Padır, M.A., 2017. Beş Faktör Kişilik Ölçeğinin Türk Kültürüne Uyarlanmas1, Sakarya University Journal of Education, 7(2), 398-408.

33. Barrick, M.R., Stewart, G.L., Piotrowiski, M. 2002, Personality and Job Performance: Test of the Mediating Effects of Motivation Among Sales Representatives, Journal of applied psychology, 87(1), 43-51.

34. Çelik, G.T., Oral, E. L., 2013. Türk İnşaat Sektöründe Çalışanların Kişilik Özelliklerinin, Örgütsel Bağlılık ve İş Tatmini ile İlişkisi. Çukurova Üniversitesi Mühendislik ve Mimarlık Fakültesi Dergisi, 28(2), 15-26.

35. Göktekin, M., 2009. Organizasyonlarda Çatışma ve İnşaat Sektörü, Yüksek Lisans Tezi, İstanbul Teknik Üniversitesi, İstanbul.

36. Gül, G.D., Acar, E., 2010. Yüklenici İnşaat Firmaları Tarafından Başvurulan Çatışma Çözüm Yaklaşımları ve Alternatif Uyuşmazlık Çözüm Yolları, 1. Proje ve Yapım Yönetimi Kongresi, ODTÜ Kültür ve Kongre Merkezi, Ankara.

37. Genç, M.İ., 2008. İnşaat Projelerinde Örgüt İçi Çatışmanın Nedenleri ve Boyutlarının Belirlenmesi, Yüksek Lisans Tezi, İstanbul Teknik Üniversitesi, İstanbul.

38. Lu, W., Wang J., 2017. The Influence of Conflict Management Sytles on Relationship Quality: The Moderating Effect of the Level of Task Conflict, International Journal of Project Management, 3, 1483-1494.

39. Tabassi, A.A., Roufechaei, K.M., Abu Bakar, A.H., Yusof, N., 2017. Linking Team Condition and Team Performance: A Transformational Leadership Aproach. Project Management Journal, 48 (2), 22-38.

40. Zang, Z., Liu, T., Chen, D., Zhang, W., 2014. Novel Algorithm for Identifying and Fusing Conflicting Data in Wireless Sensor Networks Sensors, 14 (6), 9562-9581.

41. Wu, G., Zhao, J., 2017. Effects of InterOrganizational Conflict on Construction Project Added Value in China, International Journal of Conflict Management, 28(5), 695-723.
42. Maiti, S., Choi, J., 2018. Investigation and Implementation of Conflict management Strategies to Minimize Conflict in Construction Industry, International Journal of Construction Management.

43. Altıntaş, T., 2007. İş Doyumu ve Çatışma Çözüm Stillerini Etkileyen Faktörlerin İncelenmesi, Yüksek Lisans Tezi, Ankara Üniversitesi, Ankara.

44. Özdamar, K., 1999. Paket Programlar ile İstatistiksel Veri Analizi 1. Kaan Kitabevi, Eskişehir.

45. Yaşar M., 2014. İstatistiğe Yönelik Tutum Ölçeği: Geçerlilik ve Güvenilirlik Çalışması, Pamukkale Üniversitesi Eğitim Fakültesi Dergisi, 36, Temmuz, 59-75.

46.Kılıç S. 2016. Cronbach Alfa Güvenlik Katsay1s1, Journal of Mood Disorders, 6(1), 47-48. 